\title{
Freshwater fishes of Pulosari mountain areas in Pandeglang Regency, Indonesia
}

\author{
Haryono Haryono* \\ Museum Zoologicum Bogoriense, Research Center for Biology, Indonesian Istitute of Sciences (LIPI), Widyasatwaloka Building, Jalan \\ Raya Cibinong KM 46, Cibinong, 16911, West Java, Indonesia
}

\begin{abstract}
Indonesia has many freshwater fish species but not recorded with completely, one of them from Banten Province especially in Pulosari Mountain areas of Pandeglang Regency. This study aimed to assess fish diversity, abundance, local distribution, potency, species status, bioecology aspects, and habitat condition. The study was conducted in September 2015 using survey methods. The site study was divided in five stations, the fishing gear mainly electrofishing and completed by cast net with diameter 2.5 meter. The operational of fishing gears using CPUE (catch per unit of efforts). Fish sample counted based on number of species and number of individuals for each species, then preserved and identified. Specimens were deposited in the Museum Zoologicum Bogoriense (MZB) Cibinong. The results recorded 12 species belonging to 11 families. St.2 (Cilagra river) is the most diverse with 8 species, following St.4 (Cijeruk lower) with 7 species. Barbodes binotatus is the most dominant species (19.2 ind./St.) and also widespread $(100 \%)$. Two introduce species were found i.e. Poecillia reticulata and Oreochromis niloticus. Based on potency almost balance both consume and ornamental fish. The inland waters in these areas were suitable for fish habitat.
\end{abstract}

\section{Introduction}

The Indonesian fish diversity is high in terms of freshwater fish, Kottelat et al. [1] reported at least 900 species from west Indonesia and Sulawesi. Previously, Allen [2] reported 329 species from Papua. Overall, freshwater species of Indonesia is 1248 species [3]. Moreover, the marine and freshwater fishes of Indonesia is more than 4700 species [4]. The fish diversity among Indonesian islands were reported by Kottelat et al. [1] that Java 132 species lower compare to Sumatra with 272 species and Kalimantan with 394 species.

The fish diversity of Indonesia was not optimal in term utilization for supply of protein and ornamental fish. Otherwise, the diversity and abundance of fish species tend to fall compared to the previous conditions like in Ciliwung and Cisadane [5]. It is caused by various factors, such as forest loss, water pollution, disturbance arising from the construction of dams, and over-exploitation [6].

\footnotetext{
"Corresponding author: ikharyono@yahoo.com
}

Population decline was caused by the increase of exploitation activity, destructive fishing, habitat fragmentation, and pollution. While, information of freshwater fish fauna from Indonesia is not complete. One of them from Pulosari Mountain in Pandeglang Regency, Banten Province. Therefore, a comprehensive fish fauna study covering fish diversity, abundance and distribution is needed. These information will be a base line data for future monitoring and utilization policy. Frehwater fish fauna from Banten were reported by Rachmatika et al. [7], Rachmatika \& Wahyudewantoro [8], and Gunawan \& Jumadi [9].

The documentation of freshwater fish from Pandeglang Regency was conducted. The objectives of this study were 1) inventory the freshwater fish of Pandeglang Regency, 2) to assess abundance and local distribution of fish species, 3) to assess species status (endemic, native, introduce, and protected), 4) habitat condition, and 5) to examine the fish utilization and their potency. 


\section{Materials and Methods}

Study site of freshwater fish study in Pulosari Mountain covered two districts these are Pulosari and Jiput. This area belongs to Pandeglang Regency, Banten Province (Fig 1). This study was done in September 2015 with five stations, these are:

1. Irrigation channel and rice field, Cilentung Village, District of Pulosari (S: $06^{\circ} 19.150$ and E: 105'57.396); altitude $481 \mathrm{~m}$

2. Cilagra River, Cilentung Village, District Pulosari (S: $06^{\circ} 19.166$ and E: $105^{\circ} 57.475$ ); altitude $501 \mathrm{~m}$

3. Cipadencang River, Cilentung Village, District Pulosari (S: $06^{\circ} 19.288$ and E: $105^{\circ} 56.567$ ); altitude $368 \mathrm{~m}$

4. Cijeruk River lower part, Sukacai Village, District Cijeruk, Kabupaten Pandeglang (S: $06^{\circ} 20.495$ and E: $\left.105^{\circ} 52.235\right)$; altitude $53 \mathrm{~m}$.

5. Cijeruk River upper part, Banyuresmi Village, District Jiput (S: $06^{\circ} 20.350$ and E: 105 52.320 ); altitude $57 \mathrm{~m}$.

The study started with interviewing local resident about fish diversity and species status, also its regency. Sampling stations were segment of river or stream, which is $\pm 50-100 \mathrm{~m}$ long. In stream, electrofishing gear $(12 \mathrm{~V}, 10 \mathrm{~A})$ was employed for \pm 1 hour per station (Fig. 2 ), while in river, cast net was performed for ten times per station in addition to electrofishing gear operation. The collected fish specimens were fixed by formalin $10 \%$. The collected fish were grouped based on species and number individual each species.

Physic and chemical parameter of waters covered temperature, $\mathrm{pH}$, current flow, water color, substrate, and side condition. Identification for scientific name was based on Kottelat et al. [1], Weber \& de Beaufort [10,11], Mohsin \& Ambak [12], Inger \& Chin [13], Roberts [14,15], Axelrods et al. [16], Eschmeyer [17],

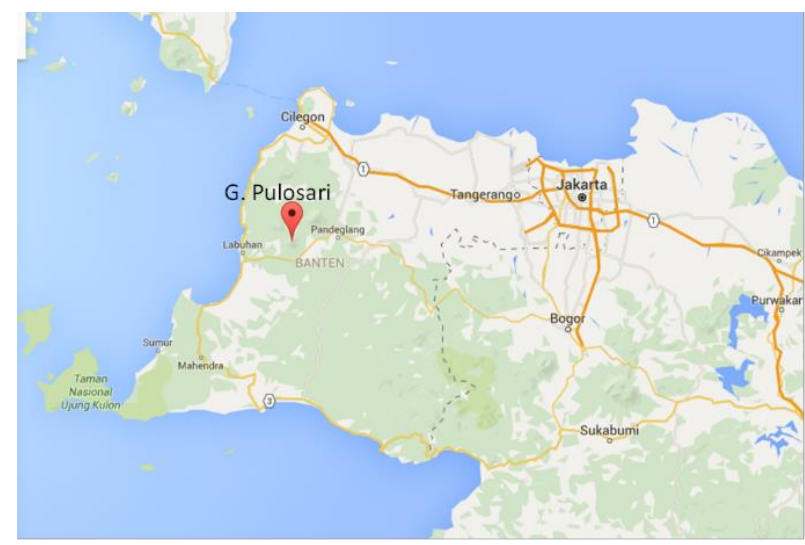

Fig. 1. Location Pulosari Mountain in Pandeglang Regency Source: http://Google map). and related references. For validation, scientific name refer to Kottelat et al. [1] and Froese \& Pauly [4]. Data analysis consist of abundance and local distribution with equation:

Abundance according to Misra [18] calculated as follow:

$$
\text { Abundance }=N_{i} / N \cdot S t_{i}
$$

Ni : number individual of species-i

N.St.i : number station species-i occurence

Local distribution or Frequency of Incidenace (FOI) was estimated according to Muchlisin \& Azizah [19] and Muchlisin et al. [20] :

$$
\text { Local distribution }=n . \text { St } / \text { N.St } x 100
$$

Ni.St : total number of locations where the species $i$ found

N.St : total number of sampling locations

Presence or absence of species at each site was used to construct a site by site similarity matrix based on Shannon-Wiener [20,21] as follow:

$$
I S=2 n / n A+n B \times 100
$$

Where,

IS : Similarity index (\%)

$2 \mathrm{n} \quad$ : number of species found at both Stations A and $\mathrm{B}$

nA : number of species found at Station A

$\mathrm{nB} \quad$ : number of species found at Station B.

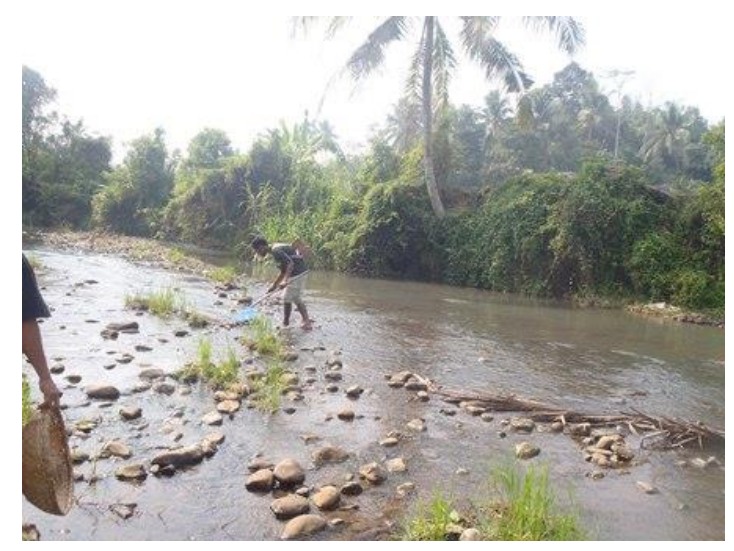

Fig. 2. Fish sampling using electrofishing (Photo: Haryono) 


\section{Results and Discussion}

\subsection{Fish Diversity}

Information about fish diversity from Pandeglang areas is lacking moreover from areas of Pulosari Mountain. Therefore, data from this study is new information and possibly important to fish resources management. The study found 12 species belonging to 11 families. Structure community in this area is equal (no predominant family) because ranges of species number between 1-2 species (Table 1). Fish species number of Pulosari Mountain is similar with Sawal Mountain areas in Ciamis Regency [23].

Both Pulosari and Sawal Mountains also have community structure most similar and the result analysis of similarity index is 0.58 . Fish species found in both locations based on local name are Beunteur, Paray, Jeler, Kehkel, Teratai, Belut, and Bogo. Commonly, the streams in mountain areas dependent to altitude that increasing altitude will be decline the fish diversity. Kottelat et al. [1] stated that the fish diversity increasing from upper part to lower part of river (Table 1). This condition caused both Pulosari and Sawal are categorized as mountain streams. Based on river order, the rivers in Pulosari areas categorized to order 1 and order 2 [24].

Community structure dependent to river order, increasing order will increase fish diversity because the river size, habitat diversity, and carrying capacity also increase. The fish diversity in these areas was also compared with Rawa Danau Nature Reserve (CARD) in Banten Province. This nature reserve is lowland area, peat land forest ecosystem remaining in Java [25]. The fish diversity in this areas recorded 24 species viz, Anabas testudineus, Belontia hasseltii, Channa striata, Clarias batrachus, Clarias nieuhofi, Trichogaster pectolaris, Trichopodus trichopterus, and Oreochromis mossambicus [25]. Likewise, if compare to Ciujung, Cimadur and Ciberang rivers in Banten are more diverse $[7,9]$. Species in these areas were different from Pulosari Mountain because different condition that upland and lowland waters.

Table 1. Fish species of Pulosari Mountain, Pandeglang Regency

\begin{tabular}{|c|c|c|c|c|c|c|c|c|}
\hline \multirow{2}{*}{ No. } & \multirow{2}{*}{ Species } & \multirow{2}{*}{ Family } & \multirow{2}{*}{ Local Name } & \multicolumn{5}{|c|}{ Stations } \\
\hline & & & & 1 & 2 & 3 & 4 & 5 \\
\hline \multicolumn{9}{|l|}{1} \\
\hline \multirow{2}{*}{2} & Anguilla marmorata & Anguillidae & Lubang/rarak & - & - & - & + & - \\
\hline & Barbodes binotatus & Cyprinidae & Beunteur & + & + & + & + & + \\
\hline 3 & Rasbora lateristriata & Cyprinidae & Paray & - & + & + & + & + \\
\hline 4 & Nemacheilus chrysolaimos & Balitroidae & Jeler & + & + & + & + & + \\
\hline 5 & Glyptothorax major & Sisoridae & Kehkel & - & - & + & - & - \\
\hline 6 & Clarias nieuhofi & Clariidae & tarai & - & + & + & - & - \\
\hline 7 & Zenarchopterus sp. & Hemirhamphidae & Jeronjong & - & - & - & + & + \\
\hline 8 & Poecillia reticulata & Poecillidae & Teratai & + & + & - & - & - \\
\hline 9 & Monopterus albus & Synbranchidae & Belut & + & + & - & + & - \\
\hline 10 & Oreochromis niloticus & Cichlidae & Mujair & - & - & - & + & - \\
\hline 11 & Channa gachua & Channidae & Bogo & + & + & - & - & - \\
\hline 12 & Macrognathus maculatus & Mastacembelidae & Berod/sarompet & - & + & + & + & + \\
\hline & Number species & & & 5 & 8 & 6 & 7 & 5 \\
\hline
\end{tabular}



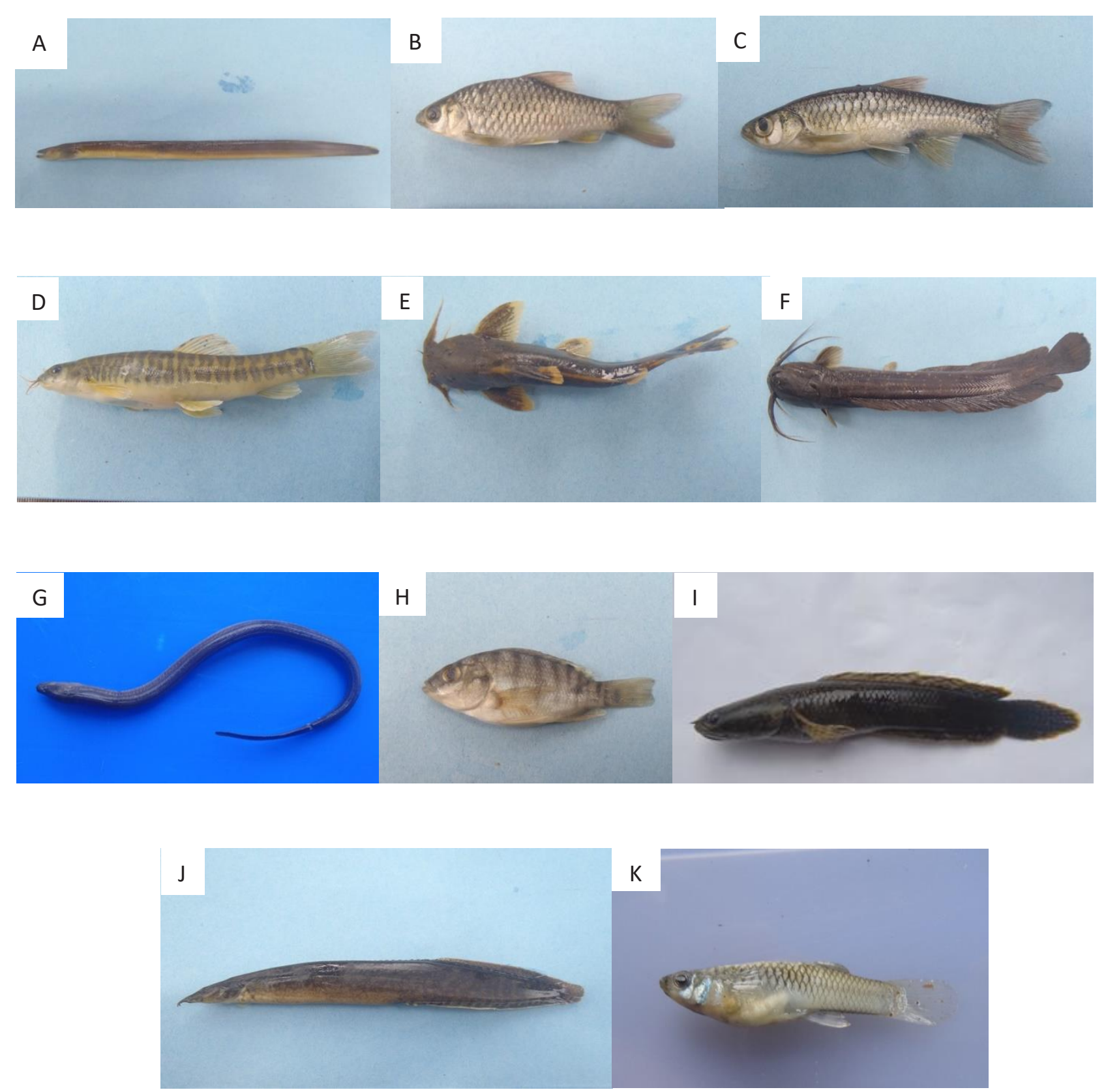

Fig. 3. Fish species from Pulosari Mountain, Padeglang Regency. (A) Anguilla marmorata, (B) Barbodes binotatus, (C) Rasbora lateristriata, (D) Nemacheilus chrysolaimos, (E) Glyptothorax major, (F) Clarias nieuhofi, (G) Monopterus albus, (H) Oreochromis niloticus, (I) Channa gachua, (J) Macrognathus maculatus, (K) Poecillia reticulata. (Photo: Haryono)

\subsection{Abundance and Local Distribution}

The abundant species in Pulosari Mountain is Barbodes binotatus (19.2 ind./St.) following Nemacheilus chrysolaimos (15.0 ind./St.) and Rasbora lateristriata (6.3 ind./St.), and other species below 5.3 ind./St. (Table 2). Habitat preferences of these species are small river or tributaries, rocky bottom, shallow and clear waters, substrate consist of sand and gravel. Waters condition in this area is similar with their preference. The most abundant species in Pulosari Mountain also similar compare to Slamet Mountain and Sawal Mountain $[23,26]$. These species also abundant in lowland rivers in Banten Province viz. Cimadur, Ciujung, and Ciberang [7]. Barbodes binotatus and Nemacheilus chrysolaimos, beside abundant also widest distributed are found in each station; following Rasbora lateristriata and Macrognathus maculatus with frequency occurrence $80 \%$ (Table 2). This showed that the four species have high adaptation, growth and reproduction in Pulosari Mountain. 


\subsection{Status of Species}

Based on species status mostly species categorized to native species, and only two as introduced species. The introduced species are Poecillia reticulata and Oreochromis niloticus. This condition showed freshwater of Pulosari Mountain not yet disturbed from introduced species. The two species are categorized as invasive species because distributed in many freshwaters in Indonesia with high abundance. The geographic distribution of Poecillia reticulata is South America and imported to Indonesia for mosquito control. Oreocrhomis niloticus is popular as fish culture in Indonesia. Unfortunately, this species not only found in pond but also distributed in many freshwaters. The geographic distribution of this species is in Africa. These species also reported from other areas in Banten $[7,9]$. Endemic species was not found in this study, probably not specific habitat in these areas. Besides, the number of endemic species in Java is also limited. Kottelat et al. [1] reported percentage endemic species of Java is lower compare to Sumatra and Kalimantan; Java 9\%, Sumatra and Kalimantan $11 \%$ and $38 \%$, respectively.

\subsection{Potency and Bioecology Aspects}

Based on potency, number of species between consume fish and ornamental fish were balance. Fish species have potency as consume fish such as Anguilla marmorata, Barbodes binotatus, Clarias nieuhofi, Monopterus albus, and Oreochromis niloticus. Two species was found which potential for both consume and ornamental fish, Rasbora lateristriata and Nemacheilus chrysolaimos (Table 2).

Species that most interested among consume fish was Eel fish (Anguilla marmorata). Eel fish was potential for both export and local market [27]. This species also has unique life cycle and categorized as catadromous fish. In the present study, one species was found with fingerling size. Glass Eel stadia growing up to Silver Eel in freshwater ecosystem, furthermore the brood stock (Silver Eel) migrating to ocean for spawning [28]. The spawning held in deep sea about $400 \mathrm{~m}$ [29]. Glass eel migrating to mouth river at night, low salinity, and high tide of sea water [28-31]. Beside Anguilla marmorata, Indonesia has 7 species of Eel fish, but only two species potential for fish cultured were Anguilla marmorata and Anguilla bicolor [32-34]. Hitherto, Eel fish cannot yet reproduce in hatchery. Therefore, the Glass eel for fish culture depend to natural catch.

Spotted Barb (Barbodes binotatus) was common species in freshwater fish with habitat in stream, lake, irrigation channel. Typical habitat of this species was shallow water, sand and mud substrate, rocky and gravel bottom, vegetation shelter, and slow or medium of water current. Geographic distribution of this species covered Sundaland, Bali, Lombok, Philipines, and Indochina
$[1,11,14]$. Spotted Barb was potential for fish consume but low price.

In the present study, the local catfish namely Clarias nieuhofi was found. This species rarely found in Java because its population depressed by Giant Catfish (Clarias gariepinus) from Africa. The Giant Catfish is popular fish consume in Indonesia and was cultivated in almost all Indonesian region. This species categorized as predator, but its population was spread into inland waters. Therefore, it might threaten native species such as Clarias nieuhofi. Morphological characters of this species were dorsal and anal united with caudal at least at their base. Distribution of this species covered Sundaland [1]. Nile fish (Oreochromis niloticus) was spread to Indonesian freshwater included in Pulosari Mountain. Macrognathus maculatus, Channa gachua, Zenarchopterus sp., and Glyptothorax major (Table 2). Interested species among ornamental fish was Spiny eel (Macrognathus maculatus). Morphological characters of this species were long body, with compressed tail, and a row of small spines along the back in front of a normal soft-rayed dorsal fin. This fish has no pelvic fin. Habitat spiny eel was slow moving water with thick vegetation or on soft mud. Distribution covered Sundaland and Burma [1]. This species founded at St.4 and St.5 (Cijeruk River).

Snakehead fish (Channa gachua) and Sucking Catfish (Glyptothorax major) were specialized in mountain waters. Habitat preferences of this species were rocky bottom, fast flowing water, and clear water. Snakehead fish was utilized for ornamental fish for a long time, otherwise sucking catfish not yet using for commercial fish. The present study also found two species as potential for both consumption and ornamental fish, these are Loach fish (Nemacheilus chrysolaimos) and Rasboras (Rasbora lateristriata). The first species was popular as crispy fish in Blitar (East Java) and Temanggung (Central Java). Morphological each species from Pulosari Mountain showed in Fig. 3.

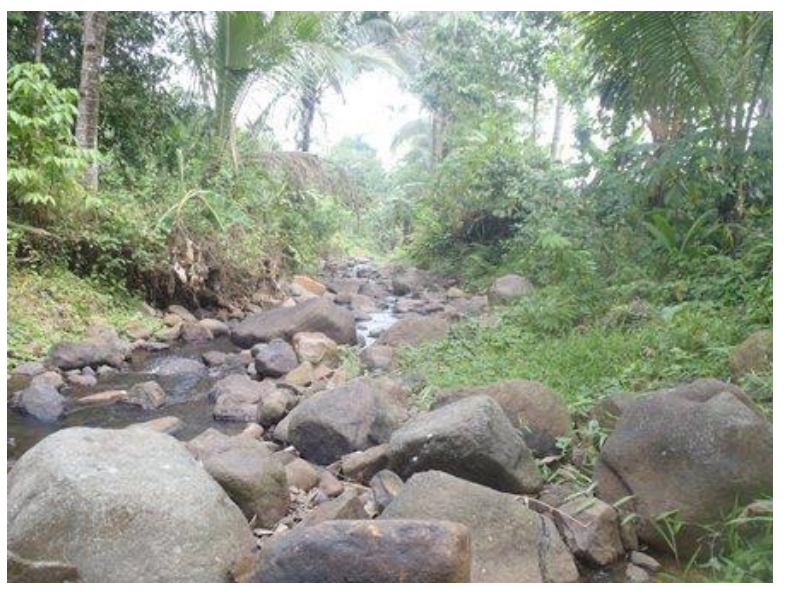

Fig. 4. Stream condition in Pulosari Mountain at dry season (Photo: Haryono) 
Table 2. Abundance, local distribution, potency, and status of fish species from Pulosari Mountain Note: C (consume fish), O (ornamental fish), O-C (both ornamental and consume fish), NA (not available), N (native), I (introduce)

\begin{tabular}{llcccc}
\hline No. & \multicolumn{1}{c}{ Species } & $\begin{array}{c}\text { Abundance } \\
\text { (ind./St) }\end{array}$ & Distribution (\%) & Potency & Status \\
\hline 1 & Anguilla marmorata & 2.0 & 20 & $\mathrm{C}$ & $\mathrm{N}$ \\
2 & Barbodes binotatus & 19.2 & 100 & $\mathrm{C}$ & $\mathrm{N}$ \\
3 & Rasbora lateristriata & 6.3 & 80 & $\mathrm{O}-\mathrm{C}$ & $\mathrm{N}$ \\
4 & Nemacheilus chrysolaimos & 15.0 & 100 & $\mathrm{O}-\mathrm{C}$ & $\mathrm{N}$ \\
5 & Glyptothorax major & 5.0 & 20 & $\mathrm{O}$ & $\mathrm{N}$ \\
6 & Clarias nieuhofi & 2.0 & 40 & $\mathrm{C}$ & $\mathrm{N}$ \\
7 & Zenarchopterus sp. & 3.5 & 40 & $\mathrm{O}$ & $\mathrm{N}$ \\
8 & Poecillia reticulata & 3.0 & 40 & $\mathrm{NA}$ & $\mathrm{I}$ \\
9 & Monopterus albus & 1.7 & 60 & $\mathrm{C}$ & $\mathrm{N}$ \\
10 & Oreochromis niloticus & 2.0 & 20 & $\mathrm{C}$ & $\mathrm{I}$ \\
11 & Channa gachua & 4.5 & 40 & $\mathrm{O}$ & $\mathrm{N}$ \\
12 & Macrognathus maculatus & 5.3 & 80 & $\mathrm{O}$ & $\mathrm{N}$ \\
\hline
\end{tabular}
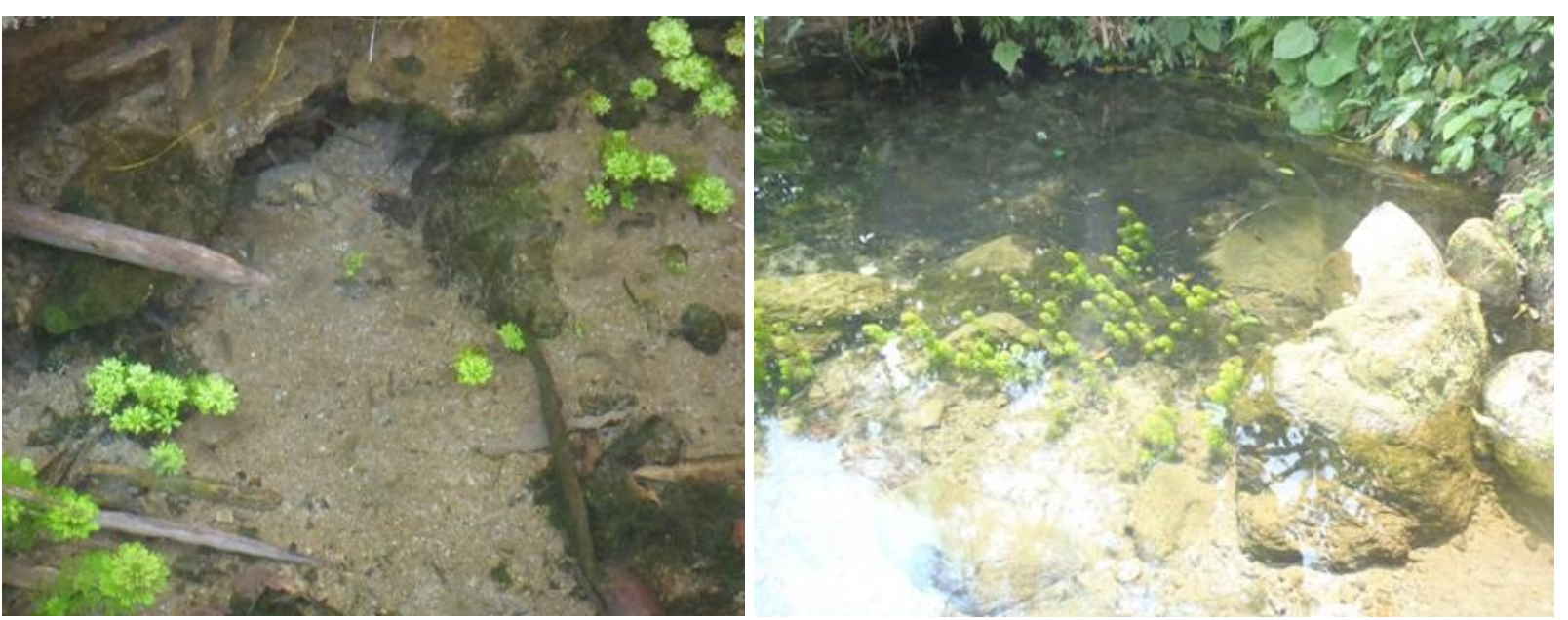

Fig. 5. The pit water of Cilagra in Pulosari Mountain (Photo: Haryono)

\subsection{Habitat Condition}

Habitat types in this area consist of stream, rice field, and stagnant pit. Based on the order of the river, most streams in Pulosari Mountain are categorized into Order 1. Characterized by rocky bottom with big size, medium flowing waters, shallow water, the substrate was gravel and sand (Fig. 4). Moreover, in some streams, there was no water because impacted by the long dry season. The fishes of this habitat viz. spotted barb and loach fish.

The Order 2 of river is Cijeruk. It has many tributaries, range wide $10-12 \mathrm{~m}$, rocky bottom, water not clear, and the environmental side dominated by rice field and plantation. The fishes found in this habitat viz. eel fish, eel spiny, spotted barb, loach, and also nile fish. Species recorded in this river (St.4 and St.5) was eight species (Table 1).
The irrigation channel (St.1) in this area was small size with the width around $1 \mathrm{~m}$. The water is clear, mud and sand bottom, also shallow water. Species in this habitat were Loach, Spotted Barb, Snakehead, and Eel fish. The dominant species were Spotted Barb and Loach. Total species number in this habitat is 5 species.

The pit water occurs in the upper part of the Cilagra River (St.2). Pit size was categorized as small, around $20 \mathrm{~m}^{2}$ with characteristics clear water, bottom consist of gravel and sand, and some aquatic water (Fig. 5). The dominant species was Spotted Barb (Barbodes binotatus). Water in this habitat is available along time. Therefore, it is potential for fish although it has high altitude $(501 \mathrm{~m}$ asl). Pit water flowing to Cilagra river and totally has eight species therefore it is the highest fish diversity compares to other stations (Table 1). 


\section{Conclusion}

Fish diversity in Pulosari Mountain is low comprised of 12 species and 11 families. The most abundant species were Spotted Barb (Barbodes binotatus) and Loach (Nemacheilus chrysolaimos). Species status mostly as native and only two as introduce species. Fish potency both consume and ornamental were balance. Habitat types were various, and the Cilagra River (St.2) has high number of fish species.

We would like to express our gratitude to the Research Center for Biology-LIPI for providing a sponsor for this study. The field coordinator by Heryanto, and all members of the team of Mt. Pulosari Project are also acknowledged.

\section{References}

1. M. Kottelat, A.J. Whitten, S.N. Kartikasari, S. Wirjoatmodjo, Freshwater fishes of Western Indonesia and Sulawesi (Periplus Edition, 1993)

2. G.R. Allen. Field guide to the Freshwater Fishes of New Guinea (Christensen Research Institute, Madang, 1991).

3. E.A. Widjaya, Y. Rahayuningsih, J.S. Rahajoe, R. Ubaidillah, I. Maryanto, E.B. Walujo, G. Semiadi, Kekinian Kenakeragaman Hayati Indonesia (LIPI Press, Jakarta, 2014).

4. R. Froese, D. Pauly. World Wide Web electronic publication.www.fishbase.org. version (04/2019).

5. R.K. Hadiaty. Journal Berita Biologi, 10(4), 491-504 (2011).

6. T. Whitten, R.E. Soeriaatmadja, S.A. Afiff, Ecology of Java and Bali (Periplus, 1990).

7. I. Rachmatika, G. Wahyudewantoro, S. Sauri. 2004, Journal Berita Biologi, 7(1), 33-40 (2004).

8. I. Rachmatika, G. Wahyudewantoro, Jurnal Iktiologi Indonesia 6(2), 93-97 (2006)

9. E.H. Gunawan, Jumadi. Jurnal Perikanan dan Kelautan, 6, 67-73 (2016)

10. M. Weber, L.F. de Beaufort, The Fishes of the IndoAustralian Archipelago. II. Malacopterygii, Myctophoidea, Ostariophysi: I. Siluroidea, (Brill, Leiden, 1993)

11. M. Weber, M.L.F. de Beaufort, The Fishes of the Indo-Australian Archipelago I-XI. (E.J. Brill Ltd., Leiden, 1916)

12. A.K.M. Mohsin, M.A. Ambak, Freshwater fishes of Peninsular Malaysia (Universiti Pertanian Malaysia, 1983)

13. R.F. Inger, P.K. Chin, Fieldiana Zoology, 45, 296 (1962)

14. T.R. Roberts, The Freshwater Fishes of Western Borneo (Kalimantan Barat, Indonesia), California Academy of Science Memoirs, 14, 210 pp (1989)
15. T.R. Roberts, Zoologische Verhandelingen, 285, 194 (1993)

16. H.R. Axelrods, G.S. Axelrods, W.E. Burgess, B.M. Scott, C.W. Emmens, R.E. Hunziker, N. Pronek, J.G. Walls, Mini Atlas of freshwater fishes, (Mini editions, T.F.H. Publications, Inc., 1995) https://doi.org/10.32491/jii.v4i2.251

17. W.N. Eschmeyer, Catalog of Fishes, 1-3, 2905pp (1988)

18. R. Misra, Ecology Workbook. (Oxford \& IB Publishing Co, New Delhi, 1968)

19.Z.A. Muchlisin, M.N. Siti-Azizah, International Journal Zoological Research, 5(2), 62-79 (2009). DOI: $10.3923 /$ ijzr.2009.62.79

20.Z.A. Muchlisin, Q. Akyun, S. Rizka, N. Fadli, M.N. Siti-Aziza. CheckList 11(2), 1-9 (2015). doi: 10.15560/11.2.1560

21. T.R.E. Southwood, Ecological Methods. (Chapman and Hall, London, 1971)

22. E.P. Odum, The Fundamental Ecology: Indonesian Translation (Gajah Mada University Press, Yogyakarta, 1971)

23. Haryono, In: I. Maryanto, M. Noerdjito, T. Partomihardjo, The ecology of Gunung Slamet, (LIPI Press, Jakarta, 2012)

24. A.M.Dias, F. L. Tejerina-Garro, Neotrop Ichthyol, 8, 587-598 (2010). https://doi.org/10.1590/S167962252010000300003.

25. R. Melish, Y R. Noor, W. Giesen, E. Widjanarti, Rudyanto. An assessment of the importance of Rawa Danau for Nature Conservation and an evaluation of resource use (Directorate General of Forest Protection and Nature Conservation and Asian Wetland Bureau, Bogor, 1993)

26. Haryono, Berita Biologi, 16(2), 147-156 (2017)

27. Haryono, Fauna Indonesia, 8(1), 22-26 (2008)

28. E.W. Tesch, The eel: Biology and Management of Anguillid Eels, Chapman and Hall, London (2003) 10.1007/978-94-009-5761-9

29. I. Matsui, Theory and practice of eel culture. AA. Balkema, Rotterdam. 133 pp (1982)

30. S. Z. Dou, K. Tsukamoto, Environmental Biology of Fishes, 67, 389-395 (2003)

31.E.D. Linton, B. Jonsson, D.L.G. Noakes, Environmental Biology of Fishes, 78, 189-192 (2007). https://doi.org/10.1007/s10641-005-1367-9

32. M.J. Miller, K. Tsukamoto K, An Introduction to Leptocephali Biology and Identification. (Ocean Research Institute, The University of Tokyo, 2004)

33. H.Y. Sugeha, J. Aoyama, K. Tsukamoto, Prosiding Seminar Limnologi, 267-275 (2006)

34. T. Arai, Biology and Ecology of Anguillid Eels, CRC Press, 340 pp. (2016) https://doi.org/10.1590/S1679-62252010000300003 